\title{
KOMPETENSI PEDAGOGIK DOSEN TERHADAP PENGEMBANGAN PEMBELAJARAN
}

\author{
Usman Moonti, Sudirman \\ Dosen Pendidikan Ekonomi \\ Universitas Negeri Gorontalo
}

\begin{abstract}
ABSTRAK
Dosen sebagai elemen yang memiliki peranan yang sangat strategis dalam proses pembelajaran, kompetensi pedagogik dosen terdapat aspek penting didalam pengembangan pembelajaran.Oleh karena itu bagaimana peran dan kontribusi kompetensi pedagogik dosen terhadap pengembangan pembelajaran.Penelitian ini menggunakan pendekatan kualitatif dengan menggunakan data sekunder dan data primer, dengan tehnik pengumpulan data sekundernya diperoleh dari referensi dan data yang telah diolah sebelumnya sedangkan data primer di peroleh berdasarkan datahasil observasi, wawancara dan diskusi terpusat.Penelitian ini bertujuan untuk memberikan informasi tentang bagaimana peran kompetensi pedagogik terhadap pengembangan pembelajaran.Untuk itu penulis memberikan simpulan bahwa kompetensi pedagogikdosen memberikan peran yang sangat besar terhadap pengembangan pembelajaran meliputi beberapa aspek yaitu :Menguasai karakteristik peserta didik, Menguasai teori belajar dan prinsip pembelajaran yang mendidik, Pengembangan kurikulum,Kegiatan pembelajaran, Pengembangan potensi peserta didik, Komunikasi dengan peserta didik,Penilaian dan evaluasi.
\end{abstract}

Kata kunci : kompetensi, pedagogik, dosen, pengembangan, pembelajaran

\section{A.PENDAHULUAN.}

Pendidikan merupakan sebuah usaha yang dilakukan untuk memberikan ilmu pengetahuan kepada tiap-tiap individu serta mendampingi peserta didik dalam proses pertumbuhan dan perkembangan sampai mereka dewasa. Sehingga tujuan pendidikan adalah usaha untukmencerdasarkan kehidupan bangsa, tanpa pendidikan yang baik, bangsa Indonesia sulit meraih masa depan yang cerah, damai dan sejahtera (Mulyasa, 2008).

$$
\text { Pendidikan yang tidak }
$$
berkualitas akan berpengaruh pada masa depan bangsa indonesia yang tidak begitu menguntungkan dan bangsa indonesia tidak dapat melakukan pembangunan nasional dengan baik, sehingga bangsa indonesia tidak memiliki daya saing. Maka dengan itu kualitas pendidikan prioritas utama didalam mengembangkan sumber daya mansuia, sehingga tujuan pendidikan di atur didalam Undang-Undang RI No 20 Tahun 2003 tentang SISDIKNAS Bab 
PEDAGOGIKA

Jurnal Ilmu Pendidikan

Volume 9 (Nomor 2) 2018

II Pasal 3 yang berbunyi:Tujuan pendidikan nasional ialah berkembangnya potensi peserta didik agar menjadi manusia-manusia yang beriman dan bertakwa kepada Tuhan Yang Maha Esa, berakhlak mulia, sehat, berilmu, cakap, kreatif, mandiri dan menjadi warga negara yang demokratis serta bertanggung jawab.

Pemerintah terus berupaya untuk memperbaiki kualitas pendidikan disemua tingkatan pendidikan, mulai dari sarana dan prasarana, kualitas pendidik atau dosen termasuk kompetensi yang dimiliki. Pemerintah telah berupaya sedemikian rupa didalam menuntut kualitas kompetensi pendidikan baik melalui sarana dan prasarana maupun melalui pengembangan pembelajarandengan harapan para dosen dapat mengembangkan kompetensinya didalam proses pembelajaran sehingga para peserta didik atau mahasiswa memiliki kualitas yang lebih dari yang lain. Disamping itu peran pemerintah sangat menentukan kualitas pendidikan secara nasional tetapi hal yangsangat menentukan adalah para tenaga pengajar atau dosen yang setiap hari berinteraksi dengan peserta didik atau mahasiswa di dalam proses pembelajaran atau perkuliahan baik di dalam kelas maupun diluar kelas.

Dosen merupakan salah satu komponen pendidikan yang memiliki peranan yang sangat penting didalam proses interaksi dengan mahasiswa baik di dalam kelas maupun di tempat terbuka, sehingga dosen adalah merupakan komponen yang sangat dekat dengan mahasiswa, maka oleh karena itu dosen harus memiliki kompetensi yang berkualitas, sehingga mereka dapat mengarahkan mahasiswa didalam proses pembelajaran sehingga mahasiswa tidak mengalami kesulitan didalam mengikuti proses pembelajaran.

$$
\text { Dalam Undang-Undang }
$$
Republik Indonesia Nomor 14 Tahun 2005 tentang Guru dan Dosen disebutkan kompetensi merupakan seperangkat pengetahuan, keterampilan, dan perilaku yang harus dimiliki, dihayati, dan dikuasai guru atau dosen dalam melaksanakan tugas keprofesionalannya baik didalam membuat rencana, melakukan proses pembelajaran dengan berdasar pada rencana maupun melaksanakan proses penilaian pembelajaran. Sedangkan menurut "Sagala" Kompetensi merupakan penggabungan dari aspek pengetahuan, sikapdan keterampilan 


\section{PEDAGOGIKA}

\section{Jurnal Ilmu Pendidikan}

Volume 9 (Nomor 2) 2018

atau adanya perpaduan antara kognitif,

seperti membuat rancangan, afektif dan psikomotorik yang diwujudkan dalam bentuk perbuatan (Sagala,2009).

Kompetensi adalah sebuah kapasitas untuk melakukan sesuatu yang dihasilkan dari sebuah proses pembelajaran, selama proses belajar belajar, stimulus akan bergabung dengan isi memori dan menyebabkan terjadinya perubahan kapasitas untuk melakukan sesuatu, Lefrancois (dalam Asmani, 2009)

Kompetensi merupakan keahlian yang dimiliki dosen didalam melaksanakan interaksi proses pembelajaran baik didalam kelas maupun diluar kelas khususnya kompetensi pedagogik.Kompetensi pedagogik adalah kemampuan yang dimiliki oleh dosen didalam mengola pembelajaran dengan mahasiswa yang meliputi membuat rencana pembelajaran, melaksanakan proses pembelajaran dan melakukan evaluasi pembelajaran (Susilo, 2011)

Dalam Undang-Undang No. 14 tahun 2017 tentang guru dan dosen dalam depdiknas (2004), Kompetensi pedagogik adalah sebuah kompetensi dimana dosen memiliki kompetensi didalam mengelola proses pembelajaran 
PEDAGOGIKA

Jurnal Ilmu Pendidikan

Volume 9 (Nomor 2) 2018

melalui metode wawanara, observasi,

diskusi terpusat. Data yang sudah terkumpul di analisis secara kualitatif untuk menarik sebuah kesimpulan dari sebuah penelitian (Sugiyono: 2008 )

C.HASIL PENELITIAN DAN PEMBAHASAN

Dari hasil riset menunjukkan bahwa kompotensi pedagogikdosen memberikan pengaruh atau berperan terhadap perkembangan pembelajaran sehingga didalam penelitian ini ada 7 aspek yang sangat mendasar yang menjadi menjadi focus dalam penelitian ini adalah sebagai berikut:

\section{Menguasai karakteristik peserta didik}

Karakteristik adalah sebuah pembeda antara mahasiswa yang satu dengan mahasiswa yang lainnya, dari hasil riset menunjukkan bahwa pada sebelum proses pembelajaran dimulai dosen dapat memastikan bahwa semua masiswa mempunyai hak dan kesempatanyang sama didalam memperoleh ilmu pengetahuan, dosen menata kondisi kelas agar proses pembelajaran setiap mahasiswa atau peserta didik mempunyai kesempatan dan rasa yang menyenangkan bagi semua peserta didik. Dsamping itu dosen tidak henti- hentinya dan terus 
PEDAGOGIKA

Jurnal Ilmu Pendidikan

Volume 9 (Nomor 2) 2018

peserta didik, disamping itu dosen juga

menjadi hal yang sangat urgen bagi menggunakan berbagai metode pembelajaran dan model pembelajaran atau tehnik dalam rangka untuk memotivasi peserta didik atau mahasiswa didalam melaksanakan proses pembelajaran sekaligus untuk mengetahuai tingkat pemahaman peserta didik atau mahasiswa terhadap materi pembelajaran, sehingga dosen dapat menyesuaikan dengan kondisi proses pembelajaran sehingga mahasiwaa dapat memahami materi pembelajaran dengan baik, disamping itu didalam proses pembelajaran dosen merencanakan proses pembelajaran atau membuat rencana pembelajaran agar tujuan pembelajaran dapat tercapai.

\section{Pengembangan kurikulum}

Dari hasil riset menunjukkan bahwa pengembangan kurikulum yang dilakukan oleh dosen lebih cenderung didalam membuatrancangan proses pembelajaran yang dijadikan sebuah acuan atau rujukan di dalam melaksanakan proses pembelajaran, rancangan pembelajaran berupa rencana pembelajaran semester (RPS) yang merupakan cakupan rencana untuk selama satu semester, didalam membuat rencana pembelajaran semester (RPS) terdapat beberapa komponen yang 
PEDAGOGIKA

Jurnal Ilmu Pendidikan

Volume 9 (Nomor 2) 2018

pembelajaran lebih aktif. (5).

seorang dosen mengkondisikan keadaan

Pengalaman belajar, (6). Pengalaman

belajar, didalam aspek ini mahasiswa

lebih cenderung didalam mengerjakan

tugas dalam bentuk peper dan makalah,

didalam proses tersebut mahasiswa

merekontruksi tentang cara membuat pepper dan makalah sebagai pengalaman belajar. (7). Materi pembelajaran, didalam materi pembelajaran yang digunakan dosen adalah materi -materi yang terupate sesuai dengan perkembangan ilmu pengetahuan dan teknologi terkini dan sesuai dengan kebutuhan mahasiswa itu sendiri.

Selain uraian diatas dosen juga membuat rancangan untuk setiap pertemuan atau sering di istilahkan dengan Satuan Acara Pembelajaran tetapi ini lebih ril karena karena hanya terdiri dari 3 indikator utama yaitu (1). Pendahuluan, yang terdiri dari menkondisikan mahasiswa untuk melaksanaknan proses pembelajaran termasuk berdoa secara bersama dan mengecek kehadiran dalam hal ini mengabsen, dosen menghubungkan materi pembelajaran sebelumnya dengan yang akan dibahas sekarang yang merupakan bagian dari apersepsi, (2). Inti, yang terdiri, bagaimana ruangan sebelum melakukan proses pembelajaran, dengan menggunakan metode dan pemodelan pembelajaran dalam rangka menciptakan suasana proses pembelajaran yang menyenangkan bagi mahasiswa, (3) Penutup, didalam kegiatan penutup ini seorang dapat mengulas kembali tentang proses pembelajaran dengan meminta kepada mahasiswa untuk memberikan simpulan dan refleksi terhadap proses pembelajaran, dan dosen mengarahkan kepada mahasiswa untuk menyampaikan pendapat dan perasaan terkait dengan kegiatan proses pembelajaran, sekaligus dosen dapat melakukan proses penilaian dan pemberian tugas kepada mahasiswa, disamping itu dosen juga memberikan informasi tentang proses pembelajaran pada pertemuan berikutnya.

Berdasarkan uraian diatas terkait proses pembuatan baik rancangan pembelajaran semester (RPS) maupun proses pembuatan satuan acara pembelajaran (SAP) bahwa kompetensi pedagogik dosen sangat berperan didalam menyusun baik RPS maupun SAP dengan rancangan yang bermutu dengan berdasarkan KKNI terhadap pengembangan pembelajaran. 
PEDAGOGIKA

Jurnal Ilmu Pendidikan

Volume 9 (Nomor 2) 2018

\section{Kegiatan pembelajaran}

Hasil riset menunjukkan bahwa responden mengatakan bahwa proses pembelajaran yang dilakukan oleh dosen sangat dipengaruhi oleh kompetensi pedagogic dosen yang dimilikinya di dalam melakukan proses pembelajaran sehingga apa yang telah dirancang di dalam satuan acara pembelajaran dapat dilakukan dengan baik.

Dosen dengan kompetensi pedagogik mereka dapat melakukan proses pembelajaran dengan menggunakan metode,strategi dan pemodelan pembelajaran sehingga pembelajaran lebih berpusat kepada mahasiswa dan dosen hanya bertindak sebagai fasilitator di dalam proses pembelajaran,dengan menggunakan tiga langkah yaitu sebagai berikut : (1). Pendahuluan, didalam pendahuluan ada beberapa komponen yang telah dilakukan oleh dosen seperti memimpin doa bersama, mengecek kehadiran mahasiswa dan melakukan apersepsi, menyampaikan tujuan pembelajaran yang akan dicapai. (2). Inti, didalam proses inti ini dosen dapat menata kondisi ruangan dengan menggunakan metode, strategi dan pemodelan pembelajaran, sehingga proses pembelajaran berpusat kepada mahasiswa, (3). Penutup, didalam proses penutup ini dosen melakukan penegasan atas materi diskusi yang telah dibahas oleh mahasiswa. Memberikan informasi kepada mahasiswa tentang tugas atau maupun memberikan informasi tentang materi yang akan dibahas pada pertemuan berikutnya.

Berdasarkan uraian diatas dapat disimpulkan bahwa komptensi pedagogik yang dimiliki oleh dosen sangat mempengaruhi dalam proses pembelajaran yang dilakukan berdasarkan pada rancangan yang telah di buat sebelumnya, proses pembelajaran sangat menarik dan menyenangkan bagi mahasiswa sehingga pembelajaran dapat berkembang sebagaimana yang menjadi harapan kita bersama.

\section{Pengembangan potensi peserta didik}

Hasil riset menunjukkan bahwa dosen telah menganalisis dengan matang tentang hasil pembelajaran yang telah dicapai oleh mahasiswa untuk mengetahui perkembangan dan kemajuan dari hasil yang telah dicapai, selain itu dosen telah merancang sebuah proses pembelajaran yang dapat 


\section{PEDAGOGIKA}

\section{Jurnal Ilmu Pendidikan}

Volume 9 (Nomor 2) 2018

meningkatkan motivasi serta dapat Berdasarkan uraian diatas bahwa diidentifikasi bakat dan minat yang dimiliki mahasiswa serta kesulitan yang dihadapi oleh mahasiswa saat belajar dan memberikan kesempatan kepada setiap mahasiswa untuk mengembangkan potensi sesuai dengan kemampuan dengan cara masing masing dan dosen memusatkan perhatian kepada mahasiswa didalam proses pembelajaran dan terus memberikan arahan agar mahasiswa, dengan mudah memahami informasi yang telah disampaikan sehingga mahasiswa dapat mengembangkan potensinya.

\section{Komunikasi dengan peserta didik}

Hasil riset menunjukkan bahwa interaksi atau komunikasi dengan peserta didik sangatlah penting, bagaimana mendengarkan pertanyaan atau tanggapan dari mahasiswa dengan baik sehingga mahasiswa merasa senang karena apa yang disampaikan menjadi perhatian dari dosen begitu juga ketika dosen menjawab pertanyaan sangat relevan sehingga jawabanjawaban yang disampaikan tidak membingungkan mahasiswa, oleh karena itu materi pelajaran dapat dipahami dengan baik, sehingga tujuan pembelajaran tercapai. 
PEDAGOGIKA

Jurnal Ilmu Pendidikan

Volume 9 (Nomor 2) 2018

yang dimilikinya maka proses evaluasi dapat lebih objektif, dengan menggunakan beberapa indikator pengukuran didalam proses evaluasi. Bentuk evaluasi yang dilakukan oleh dosen untuk mengukur tingkat ketercapaian tujuan pembelajaran baik setiap pertemuan melalui pengamatan langsung yang dilakukan oleh dosen atau dengan memberikan pertanyaan baik berupa lisan dan tulisan, proses evaluasi tengah semester yang dilakukan oleh dosen dengan memberikan ujian dalam bentuk soal esay dan soal objektif. Dalam mengukur tingkat ketercapaian tujuan proses pembelajaran dengan menggunakan dua macam pilihan baik dalam bentuk soal ujian esay atau dalam bentuk simulasi tergantung dari mata kuliah yang diampuh dosen yang bersangkutan. Setiap ujian baik dalam bentuk simulasi maupun dalam bentuk tertulis, dosen dapat memberikan koreksi langsung kepada mahasiswa sehingga mahasiswa dapat mengetahui dimana letak kekurangannya sehingga kekurangan tersebut dapat disempurnakan. Berdasarkan koreksi tersebut, dosen melakukan proses pendalaman materi atau diskusi secara terpusat antara mahasiswa dengan dosen pengampuh matakuliah.

Berdasarkan uraian diatas dapat disimpulkan bahwa mayoritas responden mengatakan kompetensi pedagogik yang dimiliki oleh dosen sangat berperan dalam melakukan proses evaluasi terhadap pembelajaran baik setiap pertemuan, tengah semester maupun akhir semester

\section{D.KESIMPULAN}

Hasil ini menunjukkan bahwa Kompetensipedagogik dosen sangat berperan terhadap pengembangan pembelajaran dengan berbagai indikator yaitu : (1) didalam membuat rancangan pembelajaran semester (RPS) untuk satu semester yang terdiri dari beberapa aspek seperti tujuan pembelajaran,indikator,kriteria dan bentuk penilaian,metode pembelajaran,pengalaman belajar dan materi pembelajaran dan satuan acara perkuliahan (SAP) berdasarkan Kurikulum berbasis kerangka kualifikasi Nasional Indonesia (KKNI). (2). Proses perkuliahan dengan mengacu pada rancangan yang telah dibuat sebelum proses pembelajaran didalam perkualiahan dilaksanakan dengan mengacu pada tiga langkah utama yaitu pendahuluan, inti dan 
PEDAGOGIKA

Jurnal Ilmu Pendidikan

Volume 9 (Nomor 2) 2018

penutup. (3). Pelaksanaan penilaian

Mata

Pelajaran

perkuliahan, dosen melakukan penilaian

secara objektif.Berdasarkan uraian

Pengetahuan

Alam.Depdiknas.

Jakarta.(Online).

(https://dnoeng.wordpress.c om/2011/07/17/teori-

pembelajaran-ipa/, diakses pada 8 Desember 2014: 18. 15 WIB).

pembelajaran.

\section{REFERENSI}

Sugiyono, (2008).Metode Penelitian

Kunatitatif

Kualitatif dan

$R \& D$. Bandung

Alfabeta.

Sugiyono. 2008. Metode Penelitian Pendidikan. Bandung : Alfabeta

Hutapea, Parulin dan Nurianna Thoha, 2008. Kompetensi Plus. PT.Gramedia Pustaka Utama Jakarta.

Lexy J. Moleong, 2002. Metode Penelitian Kualitatif, Bandung, PT. Rosda Karya

Mulyasa, E. (2008). Standar Kompetensi dan Sertifikasi Guru. Bandung: Remaja Rosdakarya.

Safwan1, dkk Pengaruh Kompetensi Dan Motivasi Terhadap Kinerja Pengelolaan Keuangan Daerah Pada Pemerintah Daerah Kabupaten Pidie Jaya.Jurnal Akuntansi ISSN 2302-0164 Pascasarjana Universitas Syiah Kuala Volume 3 no.1 februari 2014. Diakses 29 Mei 2017

Depdiknas.2004. Pedoman Khusus Pengembangan Silabus Berbasis Kompetensi SMP 